\title{
Alexander Pope: Literary Translator and Editor, from Binfield to Twickenham
}

\author{
Juan de Dios Torralbo Caballero \\ University of Córdoba \\ torralbocaballero@uco.es
}

\begin{abstract}
This paper will discuss the translations of poetry and some of the editions that Alexander Pope produced. For this, we will consider his monumental task over the translations of the work of Homer, analysing the unprecedented economic and literary implications. In addition, we shall examine Pope's imitations of Horace in order to highlight their content and underlying intentions, going on to present lastly his other work as an editor. This context will allow us to draw some conclusions from Pope's own uniqueness in the English literary and creative scene during the 18th century. Pope showed himself to be independent from the prevailing circles, being outside the radius of action of patrons and the court.
\end{abstract}

\section{Introduction}

Alexander Pope was born on 21 May 1688, during the annus mirabilis that began a political era in England and dashed the hopes of the Catholics, who were excluded from positions of high office and subject to repressive legislation (Hammond, 1986: 18). His father was a London-based merchant of Catholic faith, who retired from business in 1688 and moved to Binfield, close to Windsor forest and not far from Moor Park where Swift would live with Sir William Temple during Pope's childhood.

Pope lived some 27 years immersed in the beatus ille of Binfield. His childhood took place in this setting, with the love of his parents and his sister Racket (on his 
father's side) as well as another loved one, a nanny, who lived with them for many years, and who referred to him as "the little nightingale" on account of his pleasant tone of voice. During his early youth, a tubercular infection caused damage to his spine, leaving him with a physical deformation that remained with him his whole life.

Pope first embarked on his literary vocation with pastoral poetry and emphasised his interest by attempting new genres and trends, as was the case with his work of comic-heroic satire. This first instalment is followed by another period of roughly ten years (1715-1726) which focused on the craft of poetry translation and even its publishing, to culminate in a new phase in which he returned to cultivate satire.

In his first stage, when he composed An Essay on Criticism and The Rape of the Lock, an initial literary imitation is evident which indicates many elements that will be present throughout his literary life. Pope's primary objective was to be a poet, as Samuel Johnson asserts at the beginning of his famous biography. The use of firstperson narrative that can be seen in his poem of Chaucerian style The Temple of Fame presents an incipient assertiveness of the writer and notes from its preface the value of allegory and the moral significance of works of verbal art (Johnson, 2009: 349). Here is the end of the poem ${ }^{1}(521-524)$ :

Then teach me, Heaven! To scorn the guilty bays,

Drive from my breast that wretched lust of praise;

Unblemish'd let me live, or die unknown;

Oh, grant an honest fame, or grant me none!

Pope wrote the poem in 1711 and acknowledged the master poet. While Chaucer's work spans some two thousand verses, Pope produced 520, recognizing in a previous note his source, The House of Fame:

The hint of the following piece was taken from Chaucer's Hous of Fame. The design is in a manner entirely altered, the descriptions and most of the particular thoughts my own: yet I could not suffer it to be printed without this acknowledgment. (Pope, 1963: 40)

The 23-year-old boy shows himself to be refining his craft and reveals his concern for poetry, posing questions about literary fame and legacy. This yearning is similar to that pursued by Dryden throughout his entire life. It maintains a certain parallel with the proclamation made by Milton in Lycidas. Between Pope's readings of the English poets, the teachings of Dryden, who was a model for the fresh new creator, stand out. David B. Morris, in Alexander Pope: The Genius of Sense confirms that "there is no more profound kinship between Pope and Dryden than the belief that poetry advances by refining the achievement of the past" (Morris, 1984: 35).

The above paraphrase, itself a pretext for writing, is superseded by Pope's versions that most faithfully follow the original text. The Homeric translations comprise the central part of Pope's work as a translator. In this case it is not a matter of mere intertextuality or simple influence as it is matter of a huge number of verses whose work occupied the poet for several years. 


\section{The translations of Homer}

The completed English version of the Iliad first appeared in 1720. The Odyssey came in 1726. Pope began to translate the Iliad in 1712. This undertaking afforded the poet much pre-eminence in his own time. Considering the number of verses, his efforts must have been constant. He was not the first to express the work of Homer in verse, as at that time there was the work of Eobanus Hesssus (1540), written in Latin hexameters. Four decades later, La Valterie translated Homer into French and shortly afterwards, between 1699 and 1711, Anne Dacier ${ }^{2}$ brought out another version in 1719 (L'Iliade d'Homere). In the English arena there were also translations of Homer, specifically one from 1611 (Chapman), another published in the year of the Restoration by John Ogilby and a third in 1676 (Hobbes). It is safe to conclude that Pope would have consulted these earlier versions.

The abundant collection of notes ${ }^{3}$ that Pope added to the translation owes a considerable debt to the commentaries of the Byzantine Eustace of Thessalonica, as Johnson confirms. On examining this work, we can infer that it benefited from external assistance in the preparation of the explanations. Pope was helped by several experts such as William Broome ${ }^{4}$ - who read the commentaries of the archbishop of Thessalonica and expressed them in English - John Jortin, Dancastle or Thomas Parnell ${ }^{5}$. Parnell gave him a draft of the life of the poet living in the ninth century B.C. Jortin, who worked after Broome and another scholar from Cambridge, claimed to have forgotten the terms under which he worked for the poet, however Fenton confirmed this link as well: ${ }^{6}$

I think at first sight that his performance is very commendable, and have sent word for him to finish the 17th book, and to send it with his demands for his trouble. I have here enclosed the specimen, if the rest come before you return, I will keep them till I receive your order. (Johnson, 2009: 364)

Jortin studied in Jesus College (Cambridge) where his tutor was Styan Thirby, who recommended him to the poet. Paradoxically, Jortin and Pope never came to know each other personally. Broome, on the other hand, knew Pope in 1714, and was initially in the employment of the poet abridging notes from Eustace; and later, translating eight books of the Odyssey for him.

Another source that Pope made use of was recreated by Dacier, and so it is expressed, in the form of excusatio non petita, in the final paraphernalia of the work, for justification of authorship. This assistance explains how Pope could have completed his annotated version of the Iliad in five years, thereby culminating his pioneering work at the end of the second decade of the century. Pope referred to this work as "my long labour", as he wrote in a letter to William Broome, dated February 16, 1719.

The translation of Virgil's work published by Dryden was the first example of sales by subscription in English literature. Pope, working closely with the printer William Bowyer, prepared the preliminary page with the list of subscribers, "The names of the Subscribers." With his regular instalments of The Tatler, Steele cultivated this new 
system, also applied by Pope with the six volumes in quarto ${ }^{8}$. This is the first work of renown published completely in English in this format, those of Chaucer and Shakespeare having been published in folio. The price of each delivery, in quarto, was six guineas. ${ }^{9}$

So, the print run of his first translation was sold by subscription, producing one volume a year over the course of six years. Through this Pope garnered - along with his editor Bernard Lintot - a remarkable sum of money for that time, unheard to that point by any literary effort made in verse. The subscribers numbered 575 and there were 660 copies made. The fixed fee that Pope received for each volume amounted to 200 pounds, to which must be added the 5,320 that he earned through subscriptions. The first instalment appeared in 1715, the last in 1720. The fixed amount he received for each volume, as copyright, was not negligible for its time, marking a before and after in the history of literary editing and translation in English literature. The enormous quantity that Pope earned can be better understood if compared, for example, with Swift's best seller, for which he received $£ 200$ as copyright.

The recreation of the great Homeric work accommodated the readers of eighteenthcentury Britain, and even took the new audience of the female reader into account. The tone and style bend to a new horizon of expectations. Claudia N. Thomas explains that Pope put the Iliad on the coffee table (Thomas, 1994: 25). The techniques applied in the adaptation change, for example, the relationship between Hector and Andromaca which arises in such a way that a new sentimental dimension appears in the plot, thus winning over and captivating this new group of female readers.

Despite the fact that in the Times Literary Supplement Pope is said to translate for the "educated cognoscenti" (Tomlinson, 2003: 173), the energy of the meta-text belies the assertion. Charles Tomlinson refers to the attack of Achilles in the river Scamander clarifying the contribution of dynamic verbs and the agility of the rhyming couplets that fuel the fire and the spirit of the protagonist (XXI, 263-276):

Now bursting on his Head with thund'ring Sound,

The falling Deluge whelms the Hero round:

His loaded Shield bends to the rushing Tide;

His Feet, upborn, scarce the strong Flood divide,

Slidd'ring, and stagg'ring. On the Border stood

A spreading Elm, that overhung the Flood;

He seiz'd a bending Bough, his Steps to stay;

The Plant uprooted to his weight gave way,

Heaving the Bank, and undermining all;

Loud flash the Waters to the rushing Fall

Of the thick Foliage. The large Thunkdisplay'd

Bridg'd the rough Flood across: The Hero stay'd

On this his Weight, and rais'd upon his Hand,

Leap'd from the Chanel, and regain'd the Land.

The work is a central allusion to Homer, as much during the era of Augustus as in the eighteenth century. The Iliad represents to the Augustan English the same as the 
Aeneid did for the Romans (Brower, 1963: 127). The study conducted by Cronin and Doyle (1960:40) substantiates the mastery and retouching that Pope applied to his work, adding "tenderness and poetry", as opposed to the cold, less poetic versions of Dryden". Cronin and Doyle clarify the words of Melmoth, who studied the new response that the work received, coming as it did to new generations of readers who accepted the Homeric values set within Pope's recreation and the instructional intention that it contained, comparable with the neoclassical didacticism that typified the literature of the eighteenth century. The collection of notes is best explained under this neoclassical and Augustan paradigm.

The reflected light of his time penetrates the grandeur conferred on Jupiter, with clear resonances of Paradise Lost. So Norman Nicholson (1975: 12) establishes that Pope reduces Homer to "porcelain and cameos", an assertion which is substantiated by the acclimatisation of the age in which the translator worked and which allows Tomlinson to commend Pope's work for its mastery in translation and its faithfulness to the original. The aforementioned French translator Dacier, in her "Reflexions sur la premiere Partie de la Preface de M. Pope" (L'Illiade d'Homere, traduit en François, avec des remarques, 1719: 10-11) highlights the excessive majesty of Pope's characterisations which find a comparison in the figures of biblical heroes.

In a clarification, Pope hinted at a certain irony against the French translator, whose idealization of the Greek civilization is remarkable. In this regard, Pope is aware of the informality of the Homeric language and, as Matthew Arnold said, of the ambiguity sought in some of his words. Proof of this is Telemachus' speech in the Odyssey (XXII, 495-502), where he demonstrates how the servants of Penelope must be killed through a reasoning that is completely devoid of feeling or affection (Tomlinson, 2003:175):

Then thus the Prince. To these shall we afford

A fate so pure, as by the martial sword?

To these, the nightly prostitutes to shame,

And base revilers of our house and name?

Thus speaking, on the circling wall he strung

A ship's tough cable, from a column hung;

Near the high top he strain'd is strongly round,

Whence no contending foot could reach the ground.

The changes to be seen in style when transferring the Homeric text are consistent with the modus operandi of other works of Pope, as they are also to be noted in his modernization of Chaucer's text. When Chaucer writes "And folwed ay his bodily delyt / On women, there -as was his appetyt-" the neo-classical poet gives us "Yet let astray by Venus' soft delights, / He scarce cou'd rule some idle appetites." Half a decade later, William Cooper did manage to achieve the same effect when he raised the tone with echoes of the style of Milton. Therefore, this adaptation of the language, the maintenance of the plain register and the implementation or absence of sentimentality as appropriate to the plot, are some of the notable achievements of Alexander Pope's work. 
The classic study of Sutherland on this period emphasises the value of the writer when adapting with considerable naturalness the verses of Chaucer, as seen in the following textual pair, the first belonging to the medieval author and the second from the pen of the Augustan writer (Sutherland, 1948: 90-91):

And folwed ay his didilydelyt

On women, there-as was his appetyt-

Yet let astray by venus's soft delights,

He scarce cou'd rule some idle appetites.

Now wolde God that it were waxen night,

And that the night woldelastenevermo!

Retless he sate, invoking eve'rypow'r

To speed his bliss, and haste the happy hour.

His "Imitations of English Poets Done by the author in his youth" 10 dates from his childhood. The first of the seven compositions in this group is entitled "Chaucer" and when it is published in Miscellanies it takes the name, "A Tale of Chaucer lately found in an old Manuscript"(1-6):

Women ben full of ragerie,

Yet swinkennat sans secresie.

Thilke moral shall ye understood,

From schoole-boy's tale of fayreIrelond;

Which to the fennes hath him betake,

To filche the grey ducke fro the lake.

Mention should also be made of the view of L. G. Kelly, in The Interpreter (1979), who indicated the baroque delivery evident in Pope's version, to which Tomlinson affords some degree of value when establishing that "Pope, one must begin by admitting, had trouble with the simplicities of Homer and some of the 'lower' vocabulary, since his own diction is often extremely elevated and not easy to descend from" (Tomlinson, 2003: 174):

When Pope set his focus on translation, he may have been suffering from a degree of creative sterility, an internal crisis. His dedication to literary translation is rooted in this lack of primary inspiration, which is in its turn another manifestation of his literary energy (Quennell, 1969: 168). Another, arguably more powerful reason, is the desire to assess his small fortune, which he has been estimating with the publication of the Iliad. It is no small undertaking and to embark on the project he recruits the help of the Reverend William Broome and Elijah Fenton.

Through this sale, Pope achieved economic independence, having up to this point enjoyed not the patronage of outside benefactors, but that of his family. This marked a decisive turning point in the life of the writer. An indication of the success of his commercial translations is his new villa at Twickenham (Quennell, 1968: 127-133), which he acquired in 1719. It came to be a place of recreation for the writer, famous for 
its stone-carved grotto and the river flowing through its grounds to the delight of all who visited. It is a rural area linked to London by both land and river. His love of mythology is strikingly evident in the decoration he carried out. As he wrote to his friend Edward Blount, all that his work of art was lacking were nymphs.

1726 is another key date in the history of English editing, being the year of the appearance of his translation of the Odyssey in his production of twelve books of his own creation, along with many others of different authorship. Eight were written by Broome and four by Fenton. As much as this co-authorship might have faded his budding and stable literary fame, the economic gains did not dwindle.

The reference that Pope makes to his assistants speaks volumes. In the translation of the epic of Homer he referred to his work through the verb "translated"; in the version of the epic poem he alludes to the work by the word "undertaken", making tangential mention of "two friends of his." The craft of translation was acquiring a collective, social significance. It is, in the words of Sherburn, the ethics of collaboration (Sherburn, 1963: 269).

In the case of Broome and Fenton we can see the desire of two lyricists eager for some degree of economic revenue and emerging fame through their revision work. The new literary scene also included the reading public, expanding to include new sectors of society. In this sense, Dryden was a precedent in translating the Aeneid, which was enjoyed not only by the limited and knowledgeable cultural elite of the time, but reached the audience of prosperous merchants, professionals and female readers. The Tatler and The Spectator ${ }^{11}$ played an important role in this cultural and social achievement, educating readers in literary taste, by promulgating new principles on literary criticism and advocating the incorporation of women to the enjoyment of works of verbal art. It is possible to assess Pope's work as having been received by a significant number of women. Johnson sets the number at 575 subscribers, with about 660 copies printed. According to Pat Rogers (1795: 22), a female public made up a remarkable portion of those who received the translation of the Iliad, almost one tenth of its readers being women. Among its 609 subscribers, Pope's Odyssey boasted of more than one-tenth of its audience being female.

Thus, translation went beyond the use of auctoritas in other space-time coordinates. The changes that the translator made had a positive connotation, associated with originality, and would be considered an achievement of the creator who did not submit themselves to the source text, stricto sensu, preferring instead to defend their own creation (Davis, 2008: 246).

Another type of translation, as a general concept, is that which is seen in Pope's imitations of Horace. In this case the communicating vessels that go from the source text to the meta-text translate a degree of intentionality and certain motives that served the new writer in refining his context and starting a new literary work. 


\section{The versions of Horace}

The author adapted according to his objectives, as can be seen with his later work entitled Imitations of Horace (1733-1738) where he recreates verses of the Latin poet and modernises them with resonances of the translator's own period. This is another occasion for employing the weapon of literature in the fight against the corruption of the era of George I and George II of the house of Hanover, personified in the figure of Robert Walpole (1676-1745). Let us note, albeit in passing, that George I came to the throne in 1714 after Queen Anne died without an heir, and thanks to the law enacted in 1701 (The Establishment Act) which excluded Catholics from succession. This was a fight against the harmful consequences of the censurable activities of human beings. The English is consistent with the meaning of the original text but names are changed and a new action is presented.

The general heading is Satires and Epistles of Horace Imitated. The first part is entitled "To Mr. Fortescue." In mid-February 1733 the first part was issued, entitled "Satire I" and also known as "To Mr. Fortescue." The second part, "To Mr. Bethel" (1734), is based on the man of rural life created by Horacio, called Ofellus, who appeared in the re-write as Bethel. Another imitatio is the case of "To Lord Bolingbroke" (1737) who goes on to be a minister with Queen Anne ${ }^{12}$ in exile." To Mr. Murray" comprises a fourth, followed by 418 verses (1737) "To Augustus" together with another piece for Cotterell.

The Aristotelian technique of $\mu i \mu \eta \sigma l \varsigma$, in addition to relying on human nature, is imitatio $^{13}$ modernized. It is a form of expression accepted as a sort of literary genre towards the end of the seventeenth century and on which reflected:

A true genius, when he finds anything lofty or shinning in them, will have the skill to bring it down, take off the gloss, or quite discharge the color by some ingenious circumstance or periphrase, some addition or diminution, or by some of those figures [...]. (Pope, 2011:36)

It came from the second book of Horace, which contains eight satires, compared to the first one which has ten. In both, Horace makes use of first-person narrative, previously used by Lucilius, while his compositions are less biting than Lucilius or Juvenal. The new version, as was the custom, contained the source text parallel to the translation, so readers could compare the original with the new version. The poet from Venosa consulted a lawyer who recommended he change the satirical form for a eulogy. Trebatius, the lawyer in the original text, is embodied in the target text by William Fortescue, then an assistant of Walpole. The satire is directed at Fortescue with whom Pope, modelled as a character, converses. This exchange of 156 verses explains the concerns of Pope and, in part, reveals his motivations for writing (11-15):

F. I'd write no more.

P Not write? but then I think,

And for my soul I cannot sleep a wink.

I nod in company, I wake at night, 
Fools rush into my head, and so I write.

Pope tells him he cannot sleep because the names of certain petulant characters filled his head, in such a way that he is forced to get up and get to work. Fortescue advises him to look for a wife and refer to the medical treatises of Celsus to learn how to achieve sleep; he even advocates taking sedatives (16-20). Finally, he counsels him that if he must write, that he should praise the monarch, personified as Caesar, and in this way achieve recognition as a poet (21-22):

Or, if you needs must write, write Caesar's praise,

You'll gain at least a knighthood, or the bays.

The great disdain that the king, George II, expressed for poetry is made evident later when the poem's protagonist names the two poems that the poet laureate should compose each year, at Christmas and on the monarch's birthday, pointing out that, of course, they do not please His Majesty (33-36):

Alas! few verses touch their nicer ear;

They scarce can bear their Laureate twice a year;

And justly Caesar scorns the poet's lays,

It is to history he trusts for praise.

Thereupon he mentions Cibber in a pejorative tone, ridiculing his taste and his verses, going on to allude indirectly to some works of his own creation. His impartiality and restraint (63-68) appear very soon in a tangible form (57-62):

In this impartial glass, my muse intends

Fair to expose myself, my foes, my friends;

Publish the present age; but where my text

Is vice too high, reserve it for the next:

My foes shall wish my life a longer date,

And every friend the less lament my fate.

"To Mr. Bethel", also known as "The Second Satire of the Second Book of Horace", once again takes the name of his friend Hugh Bethel, already contained in $A n$ Essay on Man (IV, 126), and takes the form of a poem of 180 verses, where the value of virtue is emphasised without losing sight of his enmities, as is the case with Lady Mary Montagu about whom we read the following (49-52):

Avidien, or his wife (no matter which,

For him you'll call a dog, and her a bitch)

Sell their presented partridges and fruits,

And humbly live on rabbits and on roots 
This is an allusion to Edward Wortley Montagu, who married Lady Mary in 1712 and, four years later, was appointed ambassador to Constantinople. From his travels the secular work Letters from Turke is produced, which has nothing to do with moral or religious compositions, and is not in the service of good conduct. It is therefore a torchbearer in women's literature in England. Mary bore witness to the lives of Islamic women, which she describes vividly in her work. What is certain is that this woman traveller went from being a close friend of Pope's to being a target for the scornful tirade of his satires. In the previous satire she appears as "furious Sappho" (83). In 1733, seemingly aided by Hervey, they concocted a response to the poet in Verses addressed to an Imitator of Horace by a Lady, the explicitness of which is quite eloquent. Let us move on to another missive.

"To Lord Bolingbroke" is based on the beginning of first book of Horace, which is why it is also entitled "The First Epistle of the First Book of Horace." It dates from 1738 , a fact reflected in the third verse when he prays "Why will you break the Sabbath of my days?." This is a reference to Pope's 49 years compared to the more mature age of the recipient, who, giving up on his fight against the status quo, left for France (1735-1742). What is notable is the poet's use of reason when, personified in the eleventh and twelfth verses, he advises him to be prudent in avoiding that his verses are ruined, as happened to Sir Richard Blackmore who, after travelling to France and Italy, gained a greater reputation as a physicist than as an epic poet.

"To Mr. Murray," or Lord Mansfield, brings to the fore the renowned lawyer of Scottish descent, residing in London, who was noted for his eloquence as well as for the laws on trade that he promulgated. "The Sixth Epistle of the First Book of Horace" (the other name for the poem) begins with an exaltation of art and human happiness, at the same time as it stresses through a vocative to the recipient which emphasises its rhetorical style (1-4):

Not to admire, is all the art I know,

To make men happy, and to keep them so.

(Plain truth, dear Murray, needs no flowers of speech,

So take it in the very words of Creech.)

The last verses of this poem, comprising a total of 133, raise their voice against those who have squandered their fortune and their life, distracted by boundless voracity, as occurred in the case of the politician Edward Russell whose lifestyle was far from exemplary, according to the watchful eye of Pope. Nor do Kinnoul or Tyrawley find themselves worthy of praise, ambassadors who are included here for their squandered lives. Specifically, Tyrawley returned from his post in Lisbon after having lived with several wives and having conceived some fourteen children (110-115, 121-125):

Or if your life be one continued treat,

If to live well means nothing but to ear;

Up, up! cries Gluttony, 'tis break of day,

Go drive the deer, and drag the finny-prey; 
With hounds and horns go hunt an appetite.

So Russel did, but could not eat at night.

$[\ldots]$

Go dine with Chartres, in each vice outdo

$\mathrm{K}-\mathrm{l}$ 's lewd cargo, or Ty-y's crew,

From Latian sirens, French Circaean feasts;

Or for a titled punk, or foreign flame,

Renounce our country, and degrade our name?

The eight final verses are particularly striking for their use of language and for the inclusion of familiar names. One coming from a bygone era, as is the case of Rochester (John Wilmot); the other from an age that is in the process of developing when Pope wrote the poems, as is the case with Swift (136-133):

If, after all, we must with Wilmot own,

The cordial drop of life is love alone,

And Swift cry wisely, "Vive la Batallete!"

The man that loves and laughs, must sure do well.

Adieu -if this advice appear the worst,

E'en take the counsel which I gave you first:

Or better precepts if you can impart,

Why do, I'll follow them with all my heart.

Let us come now to "To Augustus", published in 1737 and based on the first epistle of the second book of Horace, which commends the emperor Augustus in hexameters as well as touching on matters such as literature and society. But in this case the letter is not directed to the emperor Augustus, but King George II who, incidentally, also has the name Augustus (George Augustus) (1-6):

While you, great patron of mankind! sustain

The balanced world, and open all the main;

Your country, chief, in arm abroad defend,

At home, with morals, arts, and laws amend;

How shall the muse from such a monarch, steal

An hour, and not defraud the public weal?

"The First Epistle of the Second Book of Horace" keeps the spirit of the original in an altered, subverted fashion since now the recipient is not a governor and a man the letters, but a monarch who spurned literature. In fact, the final run of lines (390-419) outlines a pseudo-eulogy with a marked ironic tone highlighting, in order to achieve this aim, the pronouns of first and second person singular, corresponding to the issuer (Pope) and the monarch (George II). Pope makes ample use of double meanings and hidden messages (Empson, 1995: 92-93). The central part of the poem maintains a correspondence between countries, at the same time as it carries out a review of English 
literature, to correlate the influence that Greece exercised on Rome with that which occurred between France and England.

The English updates the references to such an extent that the epistle is populated with a host of household names both native and foreign, such as Chaucer (line 37), Skelton (38), Spenser (39), Shakespeare (69, 277, 279), Ben Jonson (73, 80, 82, 388), Cowley (75, 83), Beaumont (84), Shadwell, (85), Wycherley (85), Cibber (88, 292, 319), Sidney (98), Milton (99, 172), Bentley (104), Sprat (109), Carew (109), Sedley (109), Thomas Betterton (122), Radcliffe (183), Dryden (213, 267), Roscommon (214), Addison (216), Racine (274), Corneille (214), Otway (277, 278), Congreve (287), Farquhar (288), Apha Behn (290), Blackmore (387), Quarles (387) and Dennis (388).

The second epistle of the second book of Horace is brought to mind by the English poet the same year as the previous, by way of 327 lines directed at Colonel Cotterell. "The Second Epistle of the Second Book of Horace" confirms once again Pope's independence when these remarks are considered (67-69) which also present the idea that he has thrived professionally thanks to his translation work:

$[\ldots]$ and I a poet,

But (thanks to Homer) since I live and thrive,

Indebted to no prince or peer alive

Pope continues to bring up the importance of rules with a frame of mind that is markedly neoclassical, as the same time as he objectifies the presence of a certain class of poets that bring nothing of value to the republic of letters (180-183, 200-205):

If such the plague and pains to write by rule,

Better (say I) be pleased, and play the fool;

Call, if you will, bad rhyming a disease,

It gives men happiness, or leaves them ease.

$[\ldots]$

There is a time when poets will grow dull;

I'll e'en leave verses to the boys at school:

To rules of poetry no more confined,

I'll learn to smooth and harmonise my mind,

Teach every thought within its bounds to roll,

And keep the equal measure of the soul.

These letters have their epilogue, the dating of which is explained by the title: "One Thousand Seven Hundred and Thirty-Eight; a Dialogue something like Horace", then known simply as "Epilogue to the Satires." Pope crowns his work with 427 lines. It is a dialogue in two parts that hails the triumph of corruption (I, 140-150):

Vice is undone, if she forgets her birth,

And stoops from angels to the dregs of earth:

But 'tis the fall degrades her to a whore;

Let greatness own her, and she's mean no more, 
Her birth, her beauty, crowds and courts confess,

Chaste matrons praise her, and grave bishops bless;

In golden chains the willing world she draws,

And hers the gospel is, and hers the laws,

Mounts the tribunal, lifts her scarlet head,

And sees pale Virtue carted in her stead.

Pope raises the tone, without indicating concrete figures in a personal way. Rather, he denounces a certain way of doing things. He then proclaims the extent of the corruption (160-172) marking - through ancontrasting final turn - the differences with respect to the abuses, which he openly deplores in the two lines that close the first part of the poem:

That not to be corrupted is the shame!

In soldier, churchman, patriot, man in power,

'Tis avarice all, ambition is no more!

See, all our nobles begging to be slaves!

See, all our fools aspiring to be knaves!

The wit of cheats, the courage of a whore,

Are what ten thousand envy and adore:

All, all look up, with reverential awe,

At crimes that 'scape, or triumph o'er the law:

While truth, worth, wisdom, daily they decry-

"Nothing is sacred now but villainy."

Yet may this verse (if such a verse remain)

Show there was one who held it in disdain.

The versions that Pope recreates from Horace, contrary to what occurred in the case of his Homeric adaptations, serve more as sample and pretext than as a text in itself. In this case Pope only retained the spirit and some semantic objectives of the original, substituting characters, locations, and memorable dates. Kilburn, referring to the translations of Homer in his classic study on the poet, emphasizes the "true spirit" from the source text that shines through in the target text (Kilburn, 1938:104-124). In the prologue, Pope outlines some ideas on the process of translation and summarizes that it is still a middle path between the complete freedom of the "paraphrase" and the servile approach of following the original work ad literam pedem, which leads us to think more of a recreation that reinvents and re-writes the images of Homer in a new linguistic and cultural setting. Pope preferred to extol the Homeric episodes through precise adornment. Testament of this can be found through reading the famous excerpt from the end of the sixth book of the Iliad which depicts the episode of Hector and his son.

Over the course of a decade, as Hammond concludes, Pope's wit produced little of an original nature, yet he managed to amass a personal fortune with his work and became the "cultural broker" of his era (Hammond, 2005: 33). This was his period of literary translation.This second stage contrasts with the one preceding it in that Pope began his vocation with pastoral exercises and employing epic-burlesque satire. 
The 34-year-old Pope allowed himself to jump from poet to translator; and from translator to editor. Pope wanted to be a man of letters, dedicated to the impeccable business of literature. At the same time as he turned himself to pastoral work in his grotto at Twickenham, he flourished and grew stronger thanks to the effort involved, while his translations of poetry show signs of the same verdure. He "paints" himself in his oasis precisely through "The First Satire of the Second Book of Horace Imitated", specifically in the final run of lines (122-132) as a cultivator of virtue, friendship, contentment and restraint:

The world beside may murmur, or commend.

Know, all the distant din that world can keep,

Rolls, o'er my grotto, and but soothes my sleep.

There, my retreat the best companions grace,

Chiefs out of war, and statesmen out of place.

There St. John mingles with my friendly bowl

The feast of reason and the flow of soul:

And $\mathrm{He}$, whose lightning pierced th'Iberian lines,

Now forms my quincunx, and now ranks my vines,

Or tames the genius of the stubborn plain,

Almost as quickly as he conquered Spain.

In this haven of peace is precisely where Hazlitt, who projects an image of the poet, imagines him. More specifically he speaks of the poet's muse passing his days between the majestic garden and the library (Hazlitt, 1910: 68). Here the mind of the poet is at rest, in the words of Hazlitt, in his own garden.

The allusion in the fragment to St. John responds to his friend the viscount Bolingbroke, who was forced into exiled for supporting the Jacobite cause, being pardoned in 1723 -on his return, he organized the Tory oposition-.The dual reference to Spain are regarding the Earl of Peterborough, Charles Mordaunt, who at the beginning of the century captained the troops in the taking of Barcelona, also winning Valencia in a matter of days. Another poem, entitled "On his Grotto at Twickenham" recreates his locus amoenus with all manner of detail:

Thou who shalt stop where Thames' translucent wave

Shines a broad mirror though the shadowy cave;

Where lingering drops from mineral roofs distil,

And pointed crystals break the sparkling rill,

Unpolish'd gems no ray on pride bestow,

And latent metals innocently glow:

Approach. Great Nature studiously behold!

An eye the mine without a wish for gold.

Approach: but awful! lo! The Aegerian grot,

Where, nobly pensive, St. John sat and though;

Were British sighs from dying Wyndham stole,

And the bright flame was shot through Marchmont's soul. 
Let such, such only, tread this sacred floor,

Who dare to love their country, and be poor!

"Every day with me is literally Another To-morrow; for it is exactly the same with Yesterday: it has the same Business, which is Poetry, and the same Pleasure, which is Idleness" (Griffin, 1978: 55). This configures the day-to-day of Pope, writing steadily and dedicating himself to the same thing throughout his life: poetry, a task that brought him a considerable amount of pleasure.

If focusing on literary translation yielded lucrative economic benefits for Pope; if his versions of Horace heightened the writer's prestige; the editions upon which he embarked had the effect of further aggrandising his literary name, presenting us with a writer who has retire from the normal activities of his position in which he had been involved up to that point, in order to dedicate himself to the compilation of texts for further dissemination.

\section{The business of editing literary works}

The Iliad that Lintot published suffered from unfair competition in the form of an edition in duodecimo which was imported and sold illegally by a Dutch printer. This interference drove Lintot to produce an alternative miniature edition, making improvements on the forgery by moving the notes from the final part of each book (the format of the Dutch edition) to the foot of each page, thereby facilitating consultation by the reader. This issue of piracy prevented Lintot from performing a medium-sized edition. Subsequently, more than 7,500 copies were printed over a brief period, comprising a first run of 2,500 copies. It was later necessary to return to the press to produce another 5,000 copies in a matter of days. The cheaper cost of this edition did not go on to generate much profit, making it necessary to produce high-quantity editions in order to make the printing of the reams of paper affordable.

In 1716 the publisher Edmund Curll prepared an anonymous publication that he distributed without due permission, thus trying Pope's patience. It was an edition of Court Poems. Curll was a renowned pirate editor, who stated that he found the work "in a Pocket-Book [ ...] in Westminster Hall" crediting it to Pope, Gay or to a certain "Lady of Quality", presumably Lady Mary Wortley Montagu, whose verses detail the customs of upper class and the environment which they enjoyed in the court of George I. Pope, accompanied by his editor Bernard Lintot, made an appointment with the printer, whose drink they poisoned with the result that he returned home unwell. Pope recounted this episode in A Full and True Account of a Horrid and Barbarous Revenge by Poison on the Body of Edmund Curll, Bookseller. Curll himself started out poor and became rich through the business of graphic arts. Curll can be viewed as the result of the economic growth sustained through pirate editions, pornographic publications and other prints that were saleable, as was the case with Venus in the Cloyster; or, the Nun in her Smock, brought to the market in 1724. 
Let us add that Lintot was an unparalleled editor for his time, and was a direct rival and source of competition to Tonson. Both specialized in the printing of literary translation and poetry. Linton published The Rape of the Lock in a miscellaneous collection and subsequently paid considerable royalties to the poet for his first translation of Homer. Shortly afterwards he became immersed in a controversy with his client regarding the translation of the Odyssey.

1717 is another key date in the world of publishing, being the year in which Pope completed a volume entitled Works. As well as including the full version of The Rape of the Lock, it included a translation of Chaucer, a new version of Pope's earlier poem The Temple of Fame, an ode to music which shows clear influence from Dryden ("Ode for Music on St Cecilia's Day") alongside two love poems, "Eloisa to Abelard" and "Elegy to the Memory of an Unfortunate Lady." This publication elevated Pope to becoming considered as the greatest poet of his day.

It is probable that the creative synergy that impelled Dryden towards his work of Chaucer was influenced by two factors. The most immediate was the translation and modernization of the medieval text undertaken by Dryden. Another force that impelled Pope into recreating The House of Fame is a text by Addison, published in Tatler, entitled "Tables of Fame." In addition, the work finds its origins in book XII of the Metamorphoses of Ovid. Pope's, entitled The Temple of Fame dates from 1711 and opens as follows (1-10):

In that soft season, when descending showers

Call forth the greens, and wake the rising flowers;

When opening buds salute the welcome day,

And earth relenting feels the genial ray;

As balmy sleep had charm'd my cares to rest,

And love itself was banish'd from my breast,

(What time the morn mysterious visions brings,

While purer slumbers spread their golden wings,)

A train of phantoms in wild order rose,

And, join'd, this intellectual scene compose.

In Pope's hands, the business of editing flourished, stimulating him to undertake other commercial enterprises. In fact, in May of 1722 an advertisement appeared in The Evening Post looking for translations of the works of Shakespeare to be delivered to the editor Jacob Tonson. It reads, "if any person has any editions of Tempest, Macbeth, Julius Caesar, Timos of Athens, King John, and Henry VIII, printed before the year 1620” (Quennell, 1969: 169).

A voluminous tome entitled Works, under the authorship of Buckingham, was the next of Pope's undertakings, prepared in February 1723. The courtier John Sheffield, third earl of Mulgrave and first duke of Buckingham, was a man of letters who composed in both verse and prose, including works such as Essay on Satire, Essay on Poetry, a version of Julius Caesar and a historiographical book entitled Account of the Revolution. It was the third wife of Sheffield, the illegitimate daughter of James II, who 
entrusted to Pope the task of editing the works of her late husband. In this case, the edition was ever under the watchful eye of the Whig government and its criticism, forcing some passages that favoured the house of Stuart to be removed. In January 1723 the government removed Buckingham's work from circulation, a serious blow to the motivation of the aspiring man of letters.

In early 1724 the Odyssey was in press, and Fenton strove to find a bookseller interested in the article, as we read in a letter that Fenton sent to Broome on January 9:

Tonson does not care to contract for the copy, and application has been made to Lintot, upon which he exerts the true spirit of a scoundrel, believing that he has Pope entirely at his mercy. (Sherburn, 1963: 253)

Pope paid tribute to Fenton through a poem that recognized his creative worth and was engraved at the place of his burial, in the churchyard at Stoke Parish Church. The poem echoes the verses of the metaphysical poet Crashaw ${ }^{15}$ showing clear traces of the devout writer:

This modest stone, what few vain marbles can,

May truly say, "here lies a honest man"

A poet blest beyond the poets fate $[\ldots .$.

In January 1725 the newspapers announced the works on Shakespeare and Homer (the Odyssey) looking for subscribers, marking the importance of both endeavours. As has been argued, in both publications the collaboration of several writers is evident ${ }^{16}$. The collaborators (Fenton, Broome, Jortin, Dancastle, and Parnell) achieved a degree of literary standing more than economic benefits; their work stands as a prime example of this new form of group work.

It is worth mentioning the contract for the publication of the Odyssey, preserved in the British Museum. It is dated February 18 of 1723 and stipulates certain conditions that are well worth the attention of the inquisitive scholar. The document that Lintot signed with Pope, together with the representatives of the author (Bickford and Fortescue) establishes that at the time of signing, the sum of 52.10 pounds were paid to the author. So, before publishing the first three volumes the amount of 157.10 pounds was paid, to which must be added the same amount for the publication of the fourth and fifth volumes. In this way, the amount that Pope received for each of the volumes was 315 pounds. The relationship between Pope and Lintot was not without its difficulties (Sherburn, 1963: 255), as we read in a letter written by Pope to Broome on 13 February 1725, which is repeated in another communication the following month,which reproduces part of the first:

You cannot imagine what a scoundrel Lintot is in all respects; pray send not to him for anything, or on any account correspond with or answer him. I will take care to convey the books for you for your subscribers. 
This translation was news in its time. As has been indicated, on 25 January 1725, the Daily Courant newspaper announced the sale of the translation of the Odyssey, as proposed by Pope. The next day the Evening Post launched an advertisement funded by Lintot which announced the work at a reduced price, the heading of which is expressed in the following terms: "Proposals by Bernard Lintott for his own Benefit, for Printing a translation of Homer's Odyssey by Mr. Pope."

In short, Lintot offered each volume for a guinea less that Pope, but his edition that competed with Pope's did not contain the printed name of the subscriber, although it was "in the same Manner, Size and Paper." Competition also arose regarding the form of payment and while Pope required the money to be paid in advance, Lintot allowed for the fourth and fifth volumes to be paid for at the time of delivery. On this subject, Sherburn argues that Pope's economic prosperity allowed him to compete with the bookseller, and therefore permitted payment to be made to him in cash.

Another topic worthy of mention is the matter of the earnings amassed by Fenton and Broome. Fenton, on an earlier occasion, did not show much interest in the matter of his fees. In fact, in December 1724 he writes to Broome that "I have seen Pope but twice, in passing, since I came to town. How the great affair goes on I know not, nor am inquisitive." A year later, his interests evidently change, since we read of Broome eager to catch up with Pope, saying that "we may settle affairs with Mr. Pope." In the following passage we see Broome writing in extenso to Fenton of his thoughts (Sherburn, 1963:258):

I have, my dear friend, that part to you; at least let those accounts sleep till spring. I fancy Mr. Pope will forgive us for letting the money rest in his hands. But to deal plainly, I expect a breach rather than peace from that treaty. I fear we have hunted with the lion, who, like his predecessor in Phaedrus, will take the first share mercy because he is a lion; the second because he is more brave; the third because he is of most importance; and if either of us shall presume to touch the fourth, woe be to us. This perhaps may not be the case with respect to the lucrative part, but I have strong apprehensions it will happen with regard to our reputations. Be assured Mr. Pope will not let us divide -I fear not give us our due share of honour. He is a Ceasar in Poetry, and will bear no equal.

However, it is known that Pope received the sum of 50 pounds for each volume, and gave the entire amount to his collaborators. Fenton received 200 pounds for four books; Broome earned 500 pounds for eight. In addition, other earnings coming from buyers were obtained by Fenton and Broome. For record of the justifiable public recognition we need only read the affirmation that appears after the notes, signed by Broome, which allows us to infer that it was dictated by Pope himself, in which the coauthorship of both Fenton and Broome is established, among other things.

To the collaborators in the development of the work must be added a payroll of the booksellers and publishers already mentioned (Lintot and Tonson). Tonson, in fact, supported the new man of letters in compiling a new edition of Shakespeare, which was published in 1725. The regulation of metre and the change in the number of verses led the lawyer and writer Lewis Theobald to highlight Pope's work through Shakespeare 
Restored (1726) outlining a series of mistakes that he considered to be on a scale worthy of revision. This contempt suffered by Pope, as a scholar and expert on Shakespeare, was a synergistic factor that would account for the protagonist of another work. Pope was driven to refine his criticism against Theobald in a later book, The Dunciad, where there is evidence of the motivations behind the choice of character. $\mathrm{He}$ also drafted four verses in honour of Theobald in which he recommends that he focus on his own needs rather than judging those of others. They carry the title "On Shakespeare Restored":

'Tis generous, Tibald! In thee and thy brothers,

To help us thus to read the works of others:

Never for this can just returns be shown;

For who will help us e'er to read thy own?

Alexander Pope himself supported people in the world of publishing, such as Robert Dodsley, temporarily becoming a patron to this Mansfield-born man of letters. Dodsley started his work with borrowed money and rose to become a renowned editor during the middle of the century. He published works of Samuel Johnson early on, then moving on to produce poems by other authors such as Edward Young, Mark Akenside and Thomas Gray. A Collection of Poems by Several Hands (1748) is an outstanding work during and after its publication that serves as insurance and protection for a literature considered to be first-class, elitist and classical, which went on to obtain its own means of production with regard to the widely-known literature of the time such as "Smithfield Muses" or "syncophantic laureates" (Keegan \& Haschenburger, 2009: 159) that Michael F. Suarez (1996: 307) considers to be proletarian.

Between ventures and during his maturity, Pope took to focusing on the organisation of his poems with a view to preparing the final edition of his career. Pope said "I must make a perfect edition of my Works, and then I shall have nothing to do but die" (Griffin, 1978: 35). It is the image of himself that the writer wished to have in posterity. This perfect edition, in the words of Montaigne, is inseparable from its author; in it the poet shows himself exactly as he wishes, a friend to virtue and perfection.

\section{Conclusion}

The poet who in his first phase generated the comic-epic work about the violation of a lock of hair, in his final stage dedicated himself to the composition of a sturdier satire of a meta-literary and social nature. The writer considered himself qualified, by virtue of his career and extensive success, to proclaim who were the good and who were the bad writers. The Dunciad focuses on Grub Street, a real place in London where false wisdom proliferated through writing. The work lays siege to the pretentiousness and false knowledge of pedants, launching its attacks directly against his contemporaries. The poem makes use of Gutenberg's invention to revile poor literary quality. We are 
faced with a stultifera navis that emphasizes the poorest literature through that of higher quality and, by extension, embodies a society that had broken free from its moorings. This poem exceeds the concealed limits of The Rape of the Lock. When in his maturity he composed An Essay on Man, Pope had already savoured the sweet returns of literary fame through his translations. He is innovative for his satires, for the subjects that he addressed and for the form that he recreated. He stands as a milestone in the history of translation and editing not only for his enormous dedication to his work, but also for the economic gains obtained therefrom.

A clear affirmation as a poet is that which is emphasized in An Epistle to $\mathrm{Dr}$ Arbuthnot, where Pope permits the passing of judgement on some types of poet at the same time as he speaks of himself through these verses which possess a markedly autobiographical tone. He presents us with a glitzy display of false brightness and, in fact, makes his position clear regarding this superficiality. In this regard, Pope showed himself to be independent from the prevailing circles, being - out of choice - outside the radius of action of patrons and the court (261-270):

Oh let me live my own, and die so too!

(To live and die as all I have to do:)

Maintain a poet's dignity and ease,

And see what friends, and read what books I please:

Above a patron, though I condescend

Sometimes to call a minister my friend:

I was not born for courts or great affairs;

I pay my debts, believe, and say my prayers;

Can sleep without a poem in my head,

Nor know, if Dennis be alive or dead.

In the rest of his work the writer's own representational expression also stands out. The first-person voice that strengthens the poet's presence in the body of his work varies as he advances in age, maturity and literary achievements. In the early stages, the self-image that his work presents is that of a humble poet. Later, the autobiographical aspect that resounds in his poetry (Sitter, 2011: 115-119) is that of a writer of professional and social renown, who stands out through his own particular genius. There is a world of difference between the presentation that the author gives of himself at the beginning of The Rape of the Lock ("If she inspire, and he approve my Lays"), which displays a more generic touch, and the portraits that he draws in his later works, such as The Dunciad, which are coloured with his own personality. The "humble Muse" that appears in verse 427 of Windsor Forest strengthens his character and elevates the clarity and firmness of the assertions in other succeeding works. There are several convictions that the poet lived by until his death on 30 May 1744. Between the two stages Pope enjoyed and rejoiced in his work of translating and editing. 


\section{Notes}

1. Quoted from Alexander Pope, Collected Poems, page 48.

2. A study on women's responses to the work of Pope is carried out by Claudia N. Thomas in his 1994 book, specifically in the section "Women's responses to Pope's Appeals." To explore Dacier's commentaries in more detail, see pages 48-50.

3. The clarification integrated by Broome after the notes on The Odyssey makes it clear that "I have sometimes used Madame Dacier as she has done others, in transcribing some of her remarks without particularizing them; but indeed it was through inadvertency only that her name is sometimes omitted at the bottom of the note" (Johnson, 2009: 363).

4. In the portico to his poems Broome makes sure to leave evidence of his collaboration. Another document that corroborates the commentaries that Broome made while helping Pope is a letter written by Fenton (Johnson, 2009: 363).

5. In the poem "To Mr. Pope", Parnell praises the dexterity of Pope in the musicality and the naturalness of his translation. See the article of Hester Jones (1998: 55-68) "Pope's Homer: The Shadow of Friendship" published in Proceedings of the British Academy, 1998, The British Academy, Oxford University Press, Oxford.

6. Samuel Johnson describes it in this way in his life of Pope (2009:364) deducing that this was a purely commercial ambition.

7. In 1738 the translation of Cervantes's masterpiece was published in four volumes in quarto. This design contains the editorial, organizational and typographic hallmark of Pope's translations.

8. This is Melmoth's study on the translations of Pope that was taken up by Cronin and Doyle in Pope's Iliad: An Examination by William Melmoth (Washington, D. C.: Catholic University Press, 1960:40). Regarding Dryden, Melmoth establishes that his work is cold and brings "unpoetical fidelity to the mere letter of the original", while the effort of Pope "by heightening the piece with a few judicious touches, thou hast wrought it up in all the affecting spirit of tenderness and poetry."

9. In his graphic arts workshop, Bernard Lintot created an edition of lower quality with a lower basis weight of paper, which allowed him to offer each delivery for a lower price. 250 copies were printed in folio of all volumes and 1000 in small folio, except the first volume, of which there were 1750 copies.

10. Pope recreates this fragment of Chaucer followed by six others of Spenser, Waller, Cowley, Rochester, Dorset and Swift. The quotation is taken from Collected Poems (1963).

11. No. 142 incorporated a series of love letters from Steele and addressed to his wife. It is an example of the new characters beginning to populate the pages of literary works. Claudia N. Thomas (1994: 26) points out two precedents that shed light on this new trend in the audience of the literary works: Love's Last Shift (1696) by Colley Cibber and Jane Shore (1713) by Nicholas Rowe.

12. We should bear in mind that during this reign the Tories, whose members included Pope, obtained a certain amount of power which was curtailed and eventually collapsed with the ascendance of the house of Hanover.

13. The ninth chapter of The Art of Sinking in Poetry is entitled "Of Imitation and the manners of imitating" (2011: 35-39).

14. One of the legal disputes that he fought is particularly relevant. The editor Andrew Millar had the rights of authorship of The Seasons (Thomson) and lost them when the statutory time had passed. At that point Robert Taylor sold the poem. The lawyer saw that rights of 
authorship were recognised for life. Before the case was settled on precedent, the verdict was revoked by the House of Lords in 1774

15. Richard Crashaw: The modest front of this small floor, / Believe me, reader, can say more / Than many a braver marble can, / Here lies a truly honest man. Quoted from the Cambridge English Classics edition (1904), Poems by Richard Crashaw. See page 157 of the book. The poem is entitled "An Epitaph Upon Mr. Ashton to conformable Citizen" and is appeared in "The Delights of the Muses."

16. Group work was common in other literary establishments, such as those captained by Smollet, Dumas or Edgar Wallace. Another matter of importance is whether due recognition was given to the collaborators or if, on the other hand, their names and efforts were overshadowed to the benefit and prosperity of the promoter of the work.

\section{References}

Brower, Reuben Arthur (1963): Alexander Pope: The Poetry of Allusion. Oxford, Clarendon Press.

Davis, Paul (2008): Translation and the Poet's Life. The Ethics of Translating in English Culture, 1646-1726. Oxford, Oxford University Press.

Empson, William (1995): Seven Types of Ambiguity.London, Penguin.

Griffin D.H. (1978): Alexander Pope. The Poet in the Poems. Princeton, Princeton University Press.

Hammond, Brean (1986): Pope. Brighton, The Harvester Press Limited.

- (2005): Pope amongst the Satirists 1660-1750. Devon, Northcote House Publishers. - (2011): "London and poetry to 1750." In L. Manley (ed.), The Cambridge Companion to the Literature of London. Cambridge, Cambridge University Press. 67-84.

Hazlitt, William (1910): “On Dryden and Pope.” In W. Hazlitt, Lectures on the English Poets, London, Dent, 68-85.

Johnson, Samuel (2009): "Life of Pope", Selected Writings. A Tercentenary Celebration, Peter Martin (ed.). Cambridge. The Belknap Press of Harvard University Press, 439-469.

Keegan, Bridget and Amber Hachenburger (2009): "Questioning Canonicity." In Gary Day and Bridged Keegan (eds.), The Eighteenth Century Literature Handbook. London, Continuum, 155-167.

Kilburn, Root (1938): The Poetical Career of Alexander Pope. Princeton, Princeton University Press.

Nicholson, Norman (1975): A Choice of William Cowper's Verse. London, Faber \& Faber.

Pope, Alexander (1963): Collected Poems. Dent, London.

- (1988): An Essay on Criticism. The Rape of the Lock and Epistles to Several Persons (Moral Essays). Plymouth, Northcote House.

(2007): The Rape of the Lock. Oxford, Oxford University Press.

(2008): Selected Poetry. Oxford, Oxford University Press.

(2009): The Dunciad in Four Books. London, Longman.

(2011): The Art of Sinking in Poetry. Surrey, Oneworld Classics.

Quennell, Peter (1968): Alexander Pope. The Education of Genius 1688-1728. New York, Stein and Day.

Rogers, Pat (1975): An Introduction to Pope. London, Methuen.

Sherburn, George (1963): The Early Career of Alexander Pope. New York, Russell \& Russell. 
Sitter, John (2011): The Cambridge Introduction to Eighteenth-Century Poetry. Cambridge, Cambridge University Press.

Southerland, James (1948): A Preface to Eighteenth-Century Literature. Oxford, Clarendon Press.

Suarez, Michael F. (1996): “Trafficking the Muse: Dodsley's Collection of Poems and the Question of Canon." In Alvaro Ribeiro and James G. Basker (eds.), Tradition and Transition: Women Writers, Marginal Texts, and the Eighteenth-Century Canon. Oxford, Clarendon press, 297-313.

Thomas, Claudia N. (1994): Alexander Pope and His Eighteenth-Century Women Readers. Illinois, Southern Illinois University Press.

Tomlinson, Charles (2003): Metamorphoses. Poetry and Translation. Manchester, Carcanet. 